\title{
REVIEW OF TRENDS IN FORMULATION OF FUNCTIONAL BEER
}

\author{
Milana Đ. Rošul ${ }^{* 1}$, Anamarija I. Mandić ${ }^{1}$, Aleksandra Č. Mišan ${ }^{1}$, Nataša R. Đerić ${ }^{1}$, Jelena D. Pejin ${ }^{2}$ \\ ${ }^{1}$ University of Novi Sad, Institute of Food Technology, 21000 Novi Sad, \\ Bulevar cara Lazara 1, Serbia \\ ${ }^{2}$ University of Novi Sad, Faculty of Technology, 21000 Novi Sad, Bulevar cara Lazara 1, Serbia
}

\author{
${ }^{*}$ Corresponding author: \\ Phone: +381641261144 \\ E-mail address: milana.rosul@fins.uns.ac.rs
}

\begin{abstract}
Recently, the consciousness of consumers about the food impact on health is continuously increasing. In response to that, nowadays there is a worldwide increase in consumers' demands towards innovative products. In this context, the specialty beer market has gained a lot of attention recently. Beer is one of the most consumed low-alcoholic beverages in the world. It contains some rare and important bioactive, functional compounds. By using different equipment, techniques and ingredients containing bioactive compounds, there is a possibility to formulate and to produce various beers with potential health benefits. Breweries recognized the potential for a completely new market and started producing functional beers. This review presents a detailed summary of currently available data in this field. Some of the described beers are present on the market, while the others are developed functional beer formulations published in the scientific journals, or they are approved patents. The most of the formulations are related to beers with herbs which are already used as medical plants. This paper are also describes beers with the addition of fungi Ganoderma lucidum, grape, xanthohumol, kefir, and probiotics.
\end{abstract}

Key words: brewed beverage, specialty beer, herbs, Ganoderma, xanthohumol, probiotics

\section{INTRODUCTION}

Beer is a low-alcoholic beverage produced from malted cereals (sometimes with the addition of unmalted cereals), hops, water, and yeast. It is widely consumed all over the world and it usually contains $4-6 \% \mathrm{v} / \mathrm{v}$ of ethanol. The basic raw material for beer production is malted barley but other raw materials can be used as well (for example, wheat, maize, rice, sorghum, rye, oat, etc.) (Stewart, 2013). Beer types are classified in two major groups according to the type of fermentation: lager (bottom fermented) and ale (top fermented) beers. In addition to the type, beer's character can be described by its style (amber, blonde, brown, cream, dark, golden, fruit, red, porter, pilsner, stout, strong, wheat...) (Berlitz et al., 2004). There are many different beers available on the market, worldwide. Beer is one of the most popular drinks owing to its sensory properties and also considering its low price when compared to other types of alcoholic beverages, e.g. wine (Sohrabvandi et al., 2012).

In Europe, Germany is the first in terms of beer production $(94,957,000 \mathrm{hL})$ and overall consumption $(85,532,000 \mathrm{hL})$ ac- 
cording to the statistics from 2016. Total beer production in Europe in 2016 was $415,517,000 \mathrm{hL}$ which is much more than the quantity produced in 2010 $(403,367,000 \mathrm{hL})$. Naturally, overall consumption is also growing (total amount of $375,214,000 \mathrm{hL}$ in 2016). The Czech Republic is still the leader in beer consumption per capita (143 litres). The number of active breweries doubled from about 4000 in 2010 to more than 8000 in 2016 (The Brewers of Europe, 2017).

The most important components in beer related to positive effects on human health are antioxidants, minerals, vitamins, fibre, and relatively low level of ethanol (Bamforth, 2002). Many studies indicate that moderate beer consumption is related to prevention of cardiovascular diseases, cancer, and osteoporosis (lacomino et al., 2009). The positive effects of moderate wine and beer consumption on cardiovascular diseases have been linked to their non-alcoholic compounds, primarily polyphenols (Arranz et al., 2012). Also, reasonable consumption of both beer and wine is in association with lessening the chances of developing age-induced macular degeneration (Obisesan et al., 1998). Apparently, beer is at least as good as wine when moderately consumed, regarding their compounds that are associated with potential health effects, especially polyphenols (Bamforth, 2002).

\section{Functional beers on the market}

Innovation is the key driver in all industries with no exception to the brewing industry. The consumers are constantly looking for new products on the market: a new brand, a new taste, more attractive primary and secondary packaging, a new technology, quality improvement, health benefits, etc. (Russell, 2006).

Nowadays, along with promoting a healthy lifestyle, demands for healthy food and beverages are growing. Food and beverages are recognized as a crucial factor in preventive medicine so functional food has become a very important concept (Corbo et al., 2014). The 'functional food' concept was first created in 1980's in Japan and the term was used to describe food enriched with special ingredients pro- viding health benefits. Later this concept was accepted in all parts of the world but the standard definition still does not exist because of complexity of this term (Lau et al., 2013; Alzamora et al., 2005). This concept can be transposed to the brewing industry and may find the way to the consumers. The idea of functional food is to use widely available, cheap sources of functional components in its production (Belščak-Cvitanović et al., 2017).

In response to consumer demands, first to react were brewing companies from Japan who produced new beer types with physiological functions: low calorie beers, beers containing dietary fibres, beers with a lower purine base, beers with high $\beta$ glucan concentration and many more types which are all selling well. The forecasts are that this special beer market will continue to grow and expand. This trend will carry on, under condition that the functional food sector keeps on growing and upgrading (Russell, 2006).

The increasing care about health and alcohol abuse as well as religious motives of some people inspired the brewing industry to produce low-alcohol and alcoholfree beers (Yeo and Liu, 2014). Alcoholfree beers are getting more popular around the world and they represent a huge market potential. There are many different techniques for the production of these types of beers (Burberg and Zarnkow, 2009).

Diets as a way of life is common nowadays, especially so-called 'low-carb' diets (the dietary programs that restrict carbohydrate consumption). Hence, the brewers came to the idea to start producing dietetic beers. Although most beers contain low levels of carbohydrates there are certain beers that are specifically labelled as lowcarb ones. According to US Alcohol and Tobacco Tax and Trade Bureau, only beers with less than 7 grams of carbohydrates per serving (12-ounce can) could be categorized as 'low-carb' beers (Bamforth, 2005).

Gluten is a part of a whole grain and not harmful for healthy people. Whole grains are used in many healthy diets (Huang et al., 2015). On the other hand, the gluten- 
free products are nowadays attractive part of food market because of the increasing number of coeliac disease patients and people who are gluten intolerant (Rosell and Matos, 2015). Gluten is a protein fraction present in some cereal grains, especially barley and wheat. Coeliac disease patients and those with gluten intolerance should not consume beer made from malted barley and wheat and therefore a production of beer from alternative glutenfree grains represents one solution, while another solution is a production from traditional raw materials which contain gluten and elimination of gluten throughout the brewing process (Hager et al., 2014). Most of the coeliac toxic proteins and peptides are precipitated during the mashing process and large quantity of them is also eliminated during the primary and secondary fermentation because of the precipitation of polypeptides due to the $\mathrm{pH}$ value decrease. Finally, during beer colloid stabilization process with silica gel, content of remaining proteins is reduced (Dostálek et al., 2006). Other possible options are various enzymatic treatments which will also result in a desired glutenfree product (Hager et al., 2014). Taylor et al. (2013) specified that sorghum, maize, and rice, gluten-free cereals, can be used in production of non-barley beers which is of a great interest for the brewing industry.

Gluten-free beer market is quite large but the main disadvantage is the high price of this type of beer. When gluten-free cereals and pseudocereals are used in beer production, the final product is absolutely gluten-free but has different sensory and quality parameters than malted barleybased beer (Kerpes et al., 2017). According to Codex Alimentarius and the EU-regulation 41/2009 for gluten-free food, beers with less than $20 \mathrm{mg} / \mathrm{kg}$ of gluten can be proclaimed as gluten-free beers (Knorr et al., 2016).

\section{Functional beers - research level}

A number of papers dealing with preparation and characterization of functional beer with herbs, beer with Ganoderma lucidum, beer with grape, Xanthohumol beer, estrogenic beer, kefir beer and probiotic beer are summarized in Table 1.

\section{Beer with herbs}

The addition of various herbs (sweet gale, hops...) in beer dates back to Middle Ages when people wanted to obtain new type of beer. Beer can have a pleasant flavour when mixed with medicinal or aromatic herbs or their extracts (Đorđević et al., 2016). The most important natural antioxidants in beer are polyphenols derived from malt $(70 \%)$ and hops (30\%) (Gerhäuser, 2005). The antioxidant capacity of beer can be increased by addition of herbs with antioxidative properties.

Đorđević et al. (2016) used the following medicinal parts of herbs for the preparation of the extracts: a leaf of lemon balm (Melissae officinalis), a leaf and an overhead part of thyme (Thymus vulgaris), a pseudo-fruit of common juniperi (Juniperus communis), a leaf and a root of nettle (Urticae dioica) and hop cones Lupuli strobuli (as a medicinal part of Humulus lupulus). All of these plants are already being used as spices in food industry and as remedies in traditional medicine. Dry herbal parts were extracted with ethanol-water mixture and given extracts were added to the commercial beers under sterile conditions, in sensory acceptable dosages $(0.1$ to $1.0 \mathrm{~mL} / \mathrm{L})$. Among all formulated beers, the best one was the beer with lemon balm extract in sensory terms and the beer with thyme extract when it comes to functionality of product, regarding the content of total phenols and antioxidant activity. Although the results were not pleasing in all five cases, in terms of sensory score obtained from panellists, the solution is to make different mixtures of these medicinal plants so the future experiments will be performed.

Both, lemon balm (Melissa officinalis) and thyme (Thymus vulgaris L.) contain essential oils, phenolic compounds, flavonoids and tannins. From the distant past they have been used as a therapy for many health issues in traditional medicine. Ethanol extracts of these medicinal herbs were added to pilsner beer and antimicrobial and antioxidant activities were observed. Although they expressed no antimicrobial activity against some investi- 
gated microorganisms (C. albicans and $G$. stearothermophilus), they showed microbiostatic activity against some strains ( $K$. rhizopila and L. monocytogenes). The tested beers had better antioxidant activity, determined by DPPH method. Unfortunately, general sensory impression of 100 untrained consumers was not so good and the results were unsatisfactory, so it was decided that it is worth to try again but with lower concentrations of extracts $(0.1$ to $0.3 \mathrm{~mL} / \mathrm{L}$ ) (Leskošek-Ćukalović et al., 2010b).

Tea is the second most consumed drink in the world after water (Cabrera et al., 2006). Tea is produced in three main forms and green tea is one of them along with black and oolong tea. Green tea leaf is extremely rich in polyphenols (catechins are dominant) which make up to $30 \%$ of the dry leaf weight (Lunder, 1989; Graham, 1992). Green tea is a beverage produced from leaves and in the process of making the tea, it is important to stop oxidation of the polyphenols, the main tea bioactive substances. Compounds in the green tea are almost the same as the compounds in the fresh leaf except few aromatic substances (Graham, 1992).

Belščak-Cvitanović et al. (2016) prepared encapsulated green tea extracts by electrostatic extrusion and dry green tea extracts using spray drying method. Microparticles prepared by electrostatic extrusion were made of pectin and alginate, with or without chitosan coating. Pilsner and lemon radler were control beers and they were enriched with prepared liquid and dry extracts and with hydrogel microparticles. Total phenolic content (TPC) and stability were determined immediately after beer production and every 10 days for one month of refrigerated storage at $4{ }^{\circ} \mathrm{C}$. Slightly increased total phenolic content was noticed at the end of storage in all beers with extracts. Control beer, beer with liquid extract and beer with both pectin and alginate microbeads had similar total phenolic content at the $30^{\text {th }}$ day of storage (about 200-300 mg gallic acid/L of beer), while beer with spray dried green tea extract had much higher TPC (700-1200 mg gallic acid/L of beer). The commercial radler beer with green tea hydrogel microbeads showed the best sensory qualities among the panellists as it was the least bitter and at the same time it had stronger, pleasant herbal taste. It also manifested better colloid stability during refrigerated storage.

\section{Beer with Ganoderma lucidum}

Since the earliest periods fungi have been used in an alternative medicine as herbal remedies, but lately they are also in focus of conventional medicine, pharmaceutical and cosmetic industry. Nevertheless, they are now used in the food industry in creating variety of products with enhanced functionality and the most significant one is Ganoderma (Leskošek-Ćukalović et al., 2010a). In the United States it is named Ganoderma, Reishi in Japan, and Lingzhi in China. Ganoderma's major bioactive components are polysaccharides, triterpenoids, low molecular weight proteins, sterols, ganoderic acids, unsaturated fatty acids, vitamins, and minerals (Zhou et al., 2007). Ganoderma is popular for its anticancerogenic properties but scientists still investigate this and its potential as a novel anticancerogenic agent in medical treatments (Yuen and Gohel, 2005). Triterpenoids are proven to have antioxidative, immunomodulating, and antitumour effect (Gao et al., 2004). Special bitter taste, compatible with beer, also exists owing to terpenoids.

Leskošek-Ćukalović et al. (2010 a,b) added alcohol extracts of Ganoderma to commercial beers in recommended daily doses (at a concentration of $0.1-1.5 \mathrm{~mL} / \mathrm{L}$ ) in order to get both sensory acceptable and healthy, therapeutic product. BelščakCvitanović et al. (2017) used extracts and microencapsulated polyphenolic compounds from Ganoderma mushroom extracts in alginate and pectin or in chitosanalginate/chitosan-pectin layers. Liquid or dried extracts as well as mentioned microbeads were added to Pilsner beer. The goal was to achieve longer stability, to protect microparticles and therefore prolong the retention time of encapsulated polyphenols. The important thing is that this type of beer was sensory acceptable and rated as pleasantly bitter.

Belščak-Cvitanović et al. (2016) produced encapsulated Ganoderma extracts by ele- 
ctrostatic extrusion. They also used spray drying methods to produce powdered Ganoderma extract. The aim was to increase total phenolic content and postpone polyphenolic release once it was added in beer. TPC and stability were determined at the beginning and during one month refrigerated storage at $4{ }^{\circ} \mathrm{C}$. At the end of storage, Pilsner beer with dried Ganoderma extracts had practically the same total phenolic content as radler beer with dried Ganoderma extracts (about 600 $\mathrm{mg}$ gallic acid/L of beer). The addition of hydrogel microparticles did not significantly increase TPC in comparison to the control beer. However, Pilsner beer with the addition of Ganoderma dried extracts showed the best sensory characteristics. It was preferred as it was the least bitter and had a pleasant herbal flavour. Throughout one month of refrigerated storage, Pilsner beer with Ganoderma hydrogel microbeads exhibited fluctuations in TPC. During the first month TPC increased and at the end of the one month storage it slightly decreased. Regardless, innovative and creative product with improved functionality was created.

Despotović (2017) used finely chopped or milled mushroom in $40 \%$ or $70 \% \mathrm{v} / \mathrm{v}$ ethanol or water, with or without the usage of ultrasound treatment $(45 / 60 \mathrm{kHz})$, to produce the extracts. The ratio of the fungus and extractant (ethanol or water) was 1:4 w/v. Dry mushroom body was also added to the beer, without the extraction process. The extracts showed various antimicrobial activities, but all analysed extracts had inhibitory activity against Escherichia coli 0157:H7, Yersinia enterocolitica, Listeria monocytogenes, Lactobacillus brevis, and Pediococcus cerevisiae. The best sensory ratings were obtained for extracts made of finely chopped mushroom bodies extracted with $40 \% \mathrm{v} / \mathrm{v}$ ethanol without the ultrasound treatment.

However, bitterness which originates from triterpenes is still the most dominant factor of this beer, but consumers rated it as pleasant. The results also pointed to the fact that the analysed extracts can be an important source of natural antioxidants and have a potential medical significance.
Only ethanol showed as a good extractant, and with an increase in ethanol concentration, the content of polyphenolic substances also increased. So in this case, alcoholic extracts $(70 \% \mathrm{v} / \mathrm{v})$ of milled mushroom with the use of the ultrasound treatment gave the best results. Between all the tested technological procedures for the production of mushroombased beer, the one with extract of Ganoderma lucidum added after filtration, in finished product, proved to be the most suitable.

\section{Beer with grapes}

As positive effects of moderate consumption of alcoholic beverages on human health are now well-known worldwide, researchers tend to develop new types of functional beverages (Corbo et al., 2014). One of the options is to unite beer and wine and combine their different bioactive compounds, primarily phenolic compounds and anthocyanins. The aim is to produce a special type of beer by fermenting wort combined with different ratios of must.

In 2010, Veljović et al. (2010) used must made from two different grape varieties Prokupac and Muscat Hamburg. Different ratios of must and wort (produced from $70 \%$ of barley malt and $30 \%$ of maize) were used in this study to obtain two different mixtures. One mixture was with a higher and another with a lower proportion of must (from both grape varieties).

Commercial lager beer was used as a control sample for panel sensory evaluation. Obtained products had very specific sensory characteristics in terms of fragrance, taste, aroma, body, bitterness, and freshness. Nevertheless, general impressions of the beer samples did not differ statistically, but the beer with a higher content of Muscat Hamburg was recognized as the best one. It received the highest grades among the panellists regarding the taste, even better than the commercial beer. The amount of total phenolic compounds was also determined and the same beer had the highest TPC $432.6 \mathrm{mg} \mathrm{GAE} / \mathrm{L}$ (319.4 mg GAE/L in commercial beer). These results showed that it is possible to get a product with 
pleasing sensory characteristics and enhanced functionality (Veljović et al., 2010).

Veljović (2016) produced a special type of beer from wort and grape must from three grape varieties: Prokupac, Cabernet sauvignon and Pinot noir. The sterilized must was mixed with wort, in the amount of $20 \% \mathrm{w} / \mathrm{w}$ and $30 \% \mathrm{w} / \mathrm{w}$ of grape must. Ale and lager yeast strains (Saccharomyces cerevisiae and $S$. pastorianus, respectively) were used as production micro-organisms. S. pastorianus more efficiently metabolized wort with the addition of grape must in comparison to $S$. cerevisiae and therefore yielded better overall results. As expected, beers with the addition of must contained far more phenolic compounds (470 mg GAE/L in control samples and up to seven times more in beers with the addition of grape must) and therefore had higher antioxidant capacity in comparison to control Pilsner beers. In terms of the sensory properties very favourable results were obtained. Beers with $20 \% \mathrm{w} / \mathrm{w}$ of grape must had better sensory ratings.

Consumption of such special beer type did not affect the normal heartbeat and normal blood pressure which is desirable. Compared to Pilsner beer, the main drawback is that production of this type of beer costs considerably more, mainly due to the high price of grape throughout the year. Nevertheless, beers with the addition of grape must could be a very interesting product, especially to small craft beer producers.

\section{Xanthohumol beer}

Hops, as one of the main beer ingredients, contain some compounds with positive effect on human health, e.g. xanthohumol (De Keukeleire et al., 1999; Kondo, 2003). Xanthohumol is prenylated chalcone that can be found in the hops where it represents the main prenylated flavonoid (Stevens and Page, 2004). The main drawback of its usage is that xanthohumol is in large quantities transformed into its isomeric compound-isoxanthohumol, during the wort boiling. Losses continue during fermentation, filtration, and especially during beer stabilization (Magalhães et al., 2008). This decrease of xanthohumol concentration happens because of its incom- plete extraction from the hops into the wort during wort boiling and also because of a xanthohumol adsorption to insoluble malt proteins and yeast cells during fermentation (Stevens et al., 1999). Commercial beers generally contain less than $0.2 \mathrm{mg}$ xanthohumol/L, so xanthohumolenriched hop products are being added to wort during boiling in order to increase xanthohumol concentration in beer (Wunderlich et al., 2005). Isoxanthohumol also has a positive impact on human health although it is less effective than xanthohumol (Biendl et al., 2008). Gerhauser et al. (2002) identified a chemopreventive activity of xanthohumol as well as its possible applications in terms of cancer prevention. Xanthohumol also shows a strong antioxidative effect towards hydroxyl and peroxyl radicals (Burberg and Zarnkow, 2009).

Xanthohumol is present in raw hops and hop products (pellets, $\mathrm{CO}_{2}$ extracts and ethanol extracts), as well as in xanthohumol-enriched hop products. The enhancement of xanthohumol concentration in beer can be obtained with the addition of these xanthohumol-enriched hop products in wort and by adjusting technology, but only in countries in which Bavarian Purity Law is not applied (Krottenthaler, 2009). The xanthohumol-enriched beer was first made in Munich, Germany. The special beer produced by specially adapted procedure at the Technical University of Munich in 2001 was named XAN ${ }^{\mathrm{TM}}$ wheat beer. The basic principles of this "XAN" technology" are brewing with higher original wort gravity, use of roasted malt, late hop addition in large quantities and addition of cold brewing water in order to cool the wort down to $80{ }^{\circ} \mathrm{C}$ as fast as possible to prevent isomerization of xanthohumol. The concentration of hop substances was successfully increased by 10 times and final concentration of more than $10 \mathrm{mg}$ xanthohumol/L might be reached in filtered beer (Burberg and Zarnkow, 2009).

Biendl et al. (2008) tested the addition of xanthohumol-enriched hop products to pilsner and stout/porter beer. Obtained concentrations were: $8.1 \mathrm{mg} / \mathrm{L}$ of isoxanthohumol and less than $0.1 \mathrm{mg} / \mathrm{L}$ of xan- 
thohumol in Pilsner beer and $9.0 \mathrm{mg} / \mathrm{L}$ of isoxanthohumol and $3.3 \mathrm{mg} / \mathrm{L}$ of xanthohumol in stout beer. This considerably higher content of xanthohumol in stout beer was achieved due to partial prevention of xanthohumol isomerization by ingredients used in brewing this type of beer (roasted barley, chocolate malt, etc.). Magalhães et al. (2008) also managed to produce a dark beer enriched with xanthohumol while using caramel and roasted malt, as well as roasted malt extract, combined with a special XN hop extract, instead of the dosage of standard hop products (pellets etc.). Forty grams of $\mathrm{XN}$ extract was added at the end of wort boiling (late hop dosage). This whole process was carried out under aseptic conditions (Magalhães et al., 2008).

Karabin et al. (2013) represented a new method for production of dark beers enriched with xanthohumol. Optimal temperature for the addition of xanthohumol-rich hop product to wort was $60{ }^{\circ} \mathrm{C}$. The maximum concentration of xanthohumol $(1.91 \mathrm{mg} / \mathrm{L})$ was obtained from a mixture of hopped wort and dark congress wort at a ratio of $9: 1 \mathrm{v} / \mathrm{v}$.

\section{Estrogenic beer}

Along with xanthohumol beer, there are also reports about an estrogenic beer. Prenylnaringenin is known as one of the most potent phytoestrogens (Possemiers et al., 2006). Regardless of its high activity, this hop compound and its health benefits always seemed insignificant because of its low final concentration in beer $(<100 \mu \mathrm{g} / \mathrm{L})$. However, recent studies showed that proestrogen isoxanthohumol can be easily transformed into 8-pre-nylnaringenin by human domestic bacteria in intestinal processes, so the latter concentration depends not only on the initial concentration of 8-prenylnaringenin but also on the concentration of isomerized isoxanthohumol. Given that quantity of isoxanthohumol goes upon $1-2 \mu \mathrm{g} / \mathrm{mL}$, it is obvious that its isomerization could increase final total concentration of prenylnaringenin (Possemiers et al., 2009). Osteoporosis and other problems which occur in women during postmenopause are related to the lack of estrogen. This es- trogen insufficiency causes an imbalance among bone formation and bone resorption which leads to postmenopausal osteoporosis. 8-prenylnaringenin has a role here as a prospective estrogen which can be used for therapy and prevention of postmenopausal problems such as hot flashes (Stevens and Page, 2004).

\section{Kefir beer}

Kefir grain is a complex probiotic consisting of a dozen lactic acid bacteria and yeasts. Most numerous are non-patho-genic bacteria, especially Lactobacillus sp. (John and Deeseenthum, 2015). These yeasts and bacteria from kefir grains produce many special ingredients resulting in unique taste and structure. At the same time they show unique bioactivity (Farnworth, 2006). Kefir is full of vitamins, amino acids, carbon dioxide, acetoin, alcohol and essential oils which all have health benefits (John and Deeseenthum, 2015).

Rodrigues et al. (2016) were the first to produce a functional beer by probiotic microorganisms as the only production microorganisms - a beer made with kefir grains. They also isolated and clarified an aqueous kefiran (polysaccharide), a bioactive compound which may have a significant role in human nutrition (Rodrigues et al., 2005). It can also have a role as a functional food constituent because of its anti-oxidant, anti-inflammatory and other activities (Chen et al., 2015). Rodrigues et al. (2016) added kefiran in control beer regularly fermented by Saccharomyces cerevisiae. The results showed that these special beverages had synergetic properties and health benefits from both beer polyphenols and kefir probiotics.

\section{Probiotic beer}

Earlier, probiotic food was defined as 'food containing live microorganisms believed to actively enhance health by improving the balance of microflora in the gut'. Nowadays, probiotics are defined as 'microbial cells preparations or components of microbial cells that have the beneficial effects on health and well-being of the host' (Tamime et al., 2005). Products with a main goal to contribute to gut health are in 
focus so a broad spectrum of these probiotic products is available nowadays (Rozada-Sanchez et al., 2008). Among probiotic foods the most numerous ones are dairy probiotic products but lately nondairy probiotic products are being produced (Mortazavian et al., 2012).

Sohrabvandi et al. (2010) investigated the viability of two most important bacteria used in probiotics - Lactobacillus acidophilus and Bifidobacterium lactis, in lowalcohol and non-alcoholic beer during 20 day storage at $5{ }^{\circ} \mathrm{C}$. Viability of two probiotic microorganisms was tested in the final product and during 20 days of storage, until the consumption. The most valid parameter is the number of viable probiotic cells per millilitre of beer $\left(10^{6}-10^{7}\right.$ $\mathrm{cfu} / \mathrm{mL}$ is generally accepted as an adequate level). Both probiotics, specifically $L$. acidophilus, lost their viability throughout the refrigerated storage. Hence, the authors concluded that beer is not an adequate beverage for distribution of probiotic cells to the intestine but some researchers disagree, so they continued this research.
As a result, Haffner and Pasc (2018) encapsulated Lactobacillus rhamnosus in alginate and alginate-silica carriers with the aim to improve viability of probiotic bacteria. The main goal was to effectively protect the cells during storage and further during their passing through the intestine. The release of $L$. rhamnosus from the carriers after three hours and after one week was observed. Silica-coated beads showed as better option than alginate because of alginate's porosity which allowed ethanol to diffuse into bacteria cells and it is well known that ethanol is toxic for them. Still ethanol content of $5 \% \mathrm{v} / \mathrm{v}$ was found acceptable in this experiment and there was no heavy poisoning of cells as there was only about 1-log loss of cells during one week storage in case of alginate-silica beads. From these results it can be concluded that beer, however, can be a potential probiotic beverage. These non-dairy beverages are needed because fermented dairy products can cause increased cholesterol in some people and there is also a global increase in lactose intolerance.

Table 1.

Functional ingredients used in formulation of functional beer

\begin{tabular}{|c|c|c|c|c|c|}
\hline $\begin{array}{l}\text { The functional } \\
\text { ingredient }\end{array}$ & $\begin{array}{c}\text { The form added } \\
\text { to beer }\end{array}$ & $\begin{array}{c}\text { The added } \\
\text { quantity to } 1 \mathrm{~L} \text { of } \\
\text { beer }\end{array}$ & $\begin{array}{l}\text { The type } \\
\text { of beer }\end{array}$ & $\begin{array}{c}\text { Temperature } \\
\text { and duration of } \\
\text { fermentation/ } \\
\text { storage }\end{array}$ & Reference \\
\hline \multicolumn{6}{|l|}{ Plant extract } \\
\hline $\begin{array}{l}\text { Camellia } \\
\text { sinensis }\end{array}$ & $\begin{array}{c}\text { Water extract (8 } \mathrm{g} \text { of } \\
\text { plant material: } 100 \mathrm{~mL} \text { of } \\
\text { distilled water) - } \\
\text { microencapsulation in } \\
\text { alginate/pectin or spray } \\
\text { dried green tea extract. }\end{array}$ & $\begin{array}{c}1.5 \mathrm{~g} \text { hydrogel } \\
\text { microbeads/ } \\
0.5 \mathrm{~g} \text { spray dried tea } \\
\text { extract }\end{array}$ & $\begin{array}{l}\text { Pilsner/lemon } \\
\text { radler }\end{array}$ & $\begin{array}{l}1 \text { day storage } \\
\text { at } 5^{\circ} \mathrm{C}\end{array}$ & $\begin{array}{c}\text { Belščak-Cvitanović et } \\
\text { al. (2016) }\end{array}$ \\
\hline Juniperi fructus & $\begin{array}{l}\text { Ethanol-water extract } \\
\text { (plant material:liquid } \\
\text { extract=1:2). }\end{array}$ & $0.65 \mathrm{~mL}$ & Pilsner & $\begin{array}{l}1 \text { day storage } \\
\text { at } 10^{\circ} \mathrm{C}\end{array}$ & Đorđević et al. (2016) \\
\hline Lupuli strobuli & $\begin{array}{l}\text { Ethanol-water extract } \\
\text { (plant material:liquid } \\
\text { extract }=1: 2 \text { ) }\end{array}$ & $0.70 \mathrm{~mL}$ & Pilsner & $\begin{array}{l}1 \text { day storage } \\
\text { at } 10^{\circ} \mathrm{C}\end{array}$ & Đorđević et al. (2016) \\
\hline Melissa folium & $\begin{array}{l}\text { Ethanol-water extract } \\
\text { (plant material:liquid } \\
\text { extract }=1: 2 \text { ) }\end{array}$ & $0.45 \mathrm{~mL}$ & Pilsner & $\begin{array}{l}1 \text { day storage } \\
\text { at } 10^{\circ} \mathrm{C}\end{array}$ & Đorđević et al. (2016) \\
\hline Melissa officinalis & $\begin{array}{c}\text { Extract }(70 \% \text { v/v ethanol }) \\
\text { (plant material:liquid } \\
\text { extract }=1: 5)\end{array}$ & $2-3 \mathrm{~mL}$ & Pilsner & $\begin{array}{c}7 \text { days storage } \\
\text { at } 4{ }^{\circ} \mathrm{C}\end{array}$ & $\begin{array}{c}\text { Leskošek-Ćukalović et } \\
\text { al. (2010b) }\end{array}$ \\
\hline Thymi herba & $\begin{array}{l}\text { Ethanol-water extract } \\
\text { (plant material:liquid } \\
\text { extract }=1: 2 \text { ) }\end{array}$ & $0.5 \mathrm{~mL}$ & Pilsner & $\begin{array}{l}1 \text { day storage } \\
\text { at } 10^{\circ} \mathrm{C}\end{array}$ & Đorđević et al. (2016) \\
\hline Thymus vulgaris & $\begin{array}{l}\text { Extract }(70 \% \text { v/v ethanol) } \\
\text { (plant material:liquid } \\
\text { extract }=1: 5)\end{array}$ & $2-3 \mathrm{~mL}$ & Pilsner & $\begin{array}{c}7 \text { days storage } \\
\text { at } 4{ }^{\circ} \mathrm{C}\end{array}$ & $\begin{array}{c}\text { Leskošek-Ćukalović et } \\
\text { al. (2010b) }\end{array}$ \\
\hline
\end{tabular}




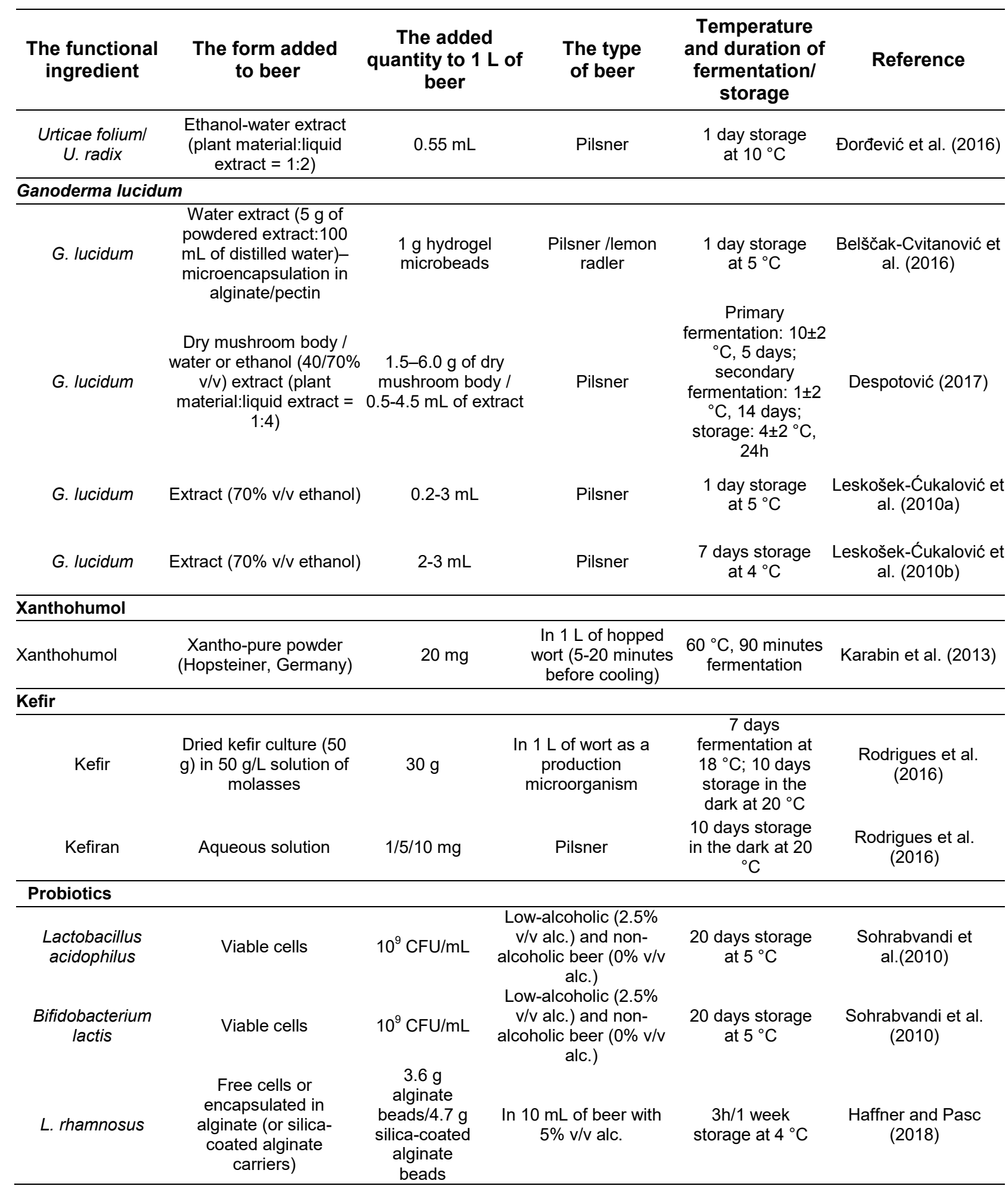

\section{Patents}

Vadimovich and Arnoldovich (2017) patented the mushroom beer and its processing. It is a beer containing an extract of medicinal and drug-edible mushroom (0.5-5.0 g/L air-dried mycelium). This document also includes the complete method - from the initial to the final stages. The final outcome is a beverage with functional properties and longer shelf life.
Liangyun patented three new beverages and their production methods in 2017. The first patented beverage formulation was a ginger beer which, in addition to fresh ginger, contained various herbs, honey, and brown sugar (Liangyun, 2017c). The fresh ginger beer was produced using the following ingredients in parts by weight: 4-6 parts of fructus Ziziphus jujuba, 3-5 parts of Dimocarpus longan, 4-6 parts of Leo- 
nurus cardiaca, 20-30 parts of fructus Hordei Geminatus, 10-20 parts of Semen Coicis, 6-10 parts of honey, 4-6 parts of brown sugar, 0.4-0.6 parts of hops, 0.40.6 part of a yeast, and 300-400 parts of mineral water (Liangyun, 2017c). It successfully prevented cold. The second patented beverage was a bitter gourd and celery beer. It did not contain fresh plants but their juices - bitter gourd juice and celery juice as well as grape seeds, honey, and buckwheat (Liangyun, 2017b). This healthcare beer was produced using by weight, 10-20 parts of bitter gourd juice, 8-12 parts of celery juice, 1-3 parts of grape seeds, 4-6 parts of honey, 3-5 parts of fructo-oligosaccharide, 0.4-0.6 part of hops, 0.4-0.6 part of brewer's yeast, 10-20 parts of buckwheat, 20-30 parts of barley malt, and 300-500 parts of mineral water. It had a pleasant taste and numerous health benefits - reduced blood fat levels and blood pressure, tonified spleen, improved immunity, inhibited oxidation and so on.

The third patented beer formulation was a beer with L-carnitine which, similarly to the previous beers, had a pleasant taste and contributed to well-being as it improved human fat metabolism and lipolysis capacity. This beer was produced using by weight, 2-4 parts of L-carnitine, 0.8-1.2 parts of chromium yeast, 0.4-0.6 part of tea polyphenol, 3-5 parts of xylo-oligosaccharide, 3-5 parts of xylitol, 2-4 parts of chitosan, 20-30 parts of barley malt, 0.60.8 part of hops, 0.6-0.8 part of brewer's yeast, and 300-500 parts of mineral water (Liangyun, 2017a).

It is important to note, however, that the statements regarding the health effects of these patented beers have not been supported by solid scientific evidence.

Bok and Jin (2018) disclosed a method for preparing a functional beer from malt and rice mixed with mushroom and seaweed fermentation extracts. After fermentation, this beverage showed antioxidant, antibacterial, and antiallergenic functions owing to the various minerals, saccharides, and amino acids. There is no available data about sensory properties of this beverage.
The most important thing for all these beverages is that their taste was not changed by mixing with diverse functional ingredients.

\section{CONCLUSIONS AND FUTURE TRENDS}

All of these formulated beers are examples of how much creativity and innovation are possible in the brewing technology. Opportunities are numerous; brewers have to answer to customers' demands and to create a market based on their needs. Just as craft brewers experimented to get brand new beers, producers of functional beer could do the same, in order to get a high-value product. A new product needs to be characterized in terms of the concentration of added functional ingredients, its health benefits, sensory profile, quality, safety, and sustainability of its production. Among functional beers, a complete novelty is a probiotic beer, obtained by incorporating probiotic microorganisms. Within this framework, the beer is likely to become a new medium for successful release of probiotic microorganisms, but the further investigations are needed to test the shelf life of this type of beer.

\section{ACKNOWLEDGEMENTS}

This work was supported by the Ministry of Science and Technological Development of Serbia, grant No. 31029.

\section{REFERENCES}

1. Alzamora, S.M., Salvatori, D., Tapia, M.S., Lopez-Malo, A., Welti-Chanes, J., Fito, P. (2005). Novel functional foods from vegetable matrices impregnated with biologically active compounds. Journal of Food Engineering, 67, 205214.

2. Arranz, S., Chiva-Blanch, G., Valderas-Martínez, P., Medina-Remón, A., Lamuela-Raventós, R.M., Estruch, R. (2012). Wine, beer, alcohol and polyphenols on cardiovascular disease and cancer. Nutrients, 4, 759-781.

3. Bamforth, C.W. (2002). Nutritional aspects of beer-a review. Nutrition Research, 22, 227-237.

4. Bamforth, C.W. (2005). Beer, carbohydrates and diet. Journal of the Institute of Brewing, 111, 259-264.

5. Belščak-Cvitanović, A., Nedović, V., Salević, A., Despotović, S., Komes, D., Nikšić, M., Bugarski, B., Leskošek-Ćukalović, I. (2017). Modification of functional quality of beer by using 
microencapsulated green tea (Camellia sinensis L.) and Ganoderma mushroom (Ganoderma lucidum L.) bioactive compounds. Chemical Industry and Chemical Engineering Quarterly, 23, 457-471.

6. Berlitz H.-D., Grosch W., Schieberle P. (2004). Food Chemistry, $3^{\text {rd }}$ edition, Springer-Verlag Berlin Heidelberg, Germany.

7. Biendl, M., Methner, F. J., Stettner, G., Walker, C. J. (2004). Brewing trials with a xanthohumolenriched hop product. Brauwelt International, 22, 182-184.

8. Bok, L.J., Jin, S. (2018). Method for preparing functional beer. KR101834112.

9. Burberg, F., Zarnkow, M. (2009). Special production methods. In Handbook of brewing: processes, technology, markets. Ed. H.M. Eßlinger, Wiley-VCH Verlag $\mathrm{GmbH}$ and Co, Weinheim, pp. 235-256.

10. Cabrera C., Artacho R., Giménez R. (2006). Beneficial effects of green tea-a review. Journal of the American College of Nutrition, 25 (2), 7999.

11. Chen, Z., Shi, J., Yang, X., Nan, B., Liu, Y., Wang, Z. (2015). Chemical and physical characteristics and antioxidant activities of the exopolysaccharide produced by Tibetan kefir grains during milk fermentation. International Dairy Journal, 43, 15-21.

12. Corbo, M.R., Bevilacqua, A., Petruzzi, L., Casanova, F.P., Sinigaglia, M. (2014). Functional beverages: the emerging side of functional foods. Comprehensive Reviews in Food Science and Food Safety, 13, 1192-1206.

13. De Keukeleire, D., De Cooman, L., Rong, H., Heyerick, A., Kalita, J., Milligan, S.R. (1999). Functional properties of hop polyphenols. In Plant polyphenols, 2. Eds. G.G. Gross, R.W. Hemingway, T. Yoshida, S.J. Branham, Springer, Boston, MA., pp. 739-760.

14. Despotović, S. (2017). Biochemical and functional properties of beer with the addition of Ganoderma lucidum mushroom, PhD Thesis, Faculty of Agriculture, University of Belgrade, Serbia.

15. Divya, J.B., Varsha, K.K., Madhavan, K., Ismail, N.B, Pandey, A. (2012). Probiotic fermented foods for health benefits. Engineering in Life Sciences, 12, 377-390.

16. Đorđević, S., Popović, D., Despotović, S., Veljović, M., Atanacković, M., Cvejić, J., Nedović, V., Leskošek-Ćukalović, I. (2016). Extracts of medicinal plants as functional beer additives. Chemical Industry and Chemical Engineering Quarterly, 22, 301-308.

17. Dostálek P., Hochel I., Méndez E., Hernando A., Gabrovská D. (2006). Immunochemical determination of gluten in malts and beers. Food Additives and Contaminants, 23 (11), 10741078.

18. Farnworth, E.R. (2006). Kefir - A complex probiotic. In Food science and technology bulletin: functional foods. Ed. G.R. Gibson, IFIS Publishing, Shinfield, pp. 1-17.

19. Gao, H., Zhou, F. (2004). Chemopreventive and tumoricidal properties of Ling Zhi mushroom Ganoderma lucidum (W.Curt.: Fr.)
Lloyd (Aphyllophoromycetideae). Part II. Mechanism considerations (Review). International Journal of Medicinal Mushrooms, 6 (3), 219-230.

20. Gerhäuser, C. (2005). Beer constituents as potential cancer chemopreventive agents. European Journal of Cancer, 41, 1941-1954.

21. Gerhäuser, C., Alt, A., Heiss, E., Gamal-Eldeen, A., Klimo, K., Knauft, J.,Neumann, I., Scherf, H-R., Frank, N., Bartsch, H., Becker, H. (2002). Cancer chemopreventive activity of xanthohumol, a natural product derived from hop. Molecular Cancer Therapeutics, 1 (11), 959-969.

22. Graham, H.N. (1992). Green tea composition, consumption, and polyphenol chemistry. Preventive Medicine, 21, 334-350.

23. Haffner, F.B., Pasc, A. (2018). Freeze-dried alginate-silica microparticles as carriers of probiotic bacteria in apple juice and beer. LWT - Food Science and Technology, 91, 175-179.

24. Hager, A.S., Taylor, J.P., Waters, D.M., Arendt, E.K. (2014). Gluten free beer - A review. Trends in Food Science and Technology, 36, 44-54.

25. Huang, T., Xu, M., Lee, A., Cho, S., Qi, L. (2015). Consumption of whole grains and cereal fiber and total and cause-specific mortality: prospective analysis of 367,442 individuals. BMC Medicine, 13 (1), 59.

26. Iacomino, G., Tedesco, I., Russo, G. L. (2009). Biological properties of beer and its components compared to wine. In Beer in health and disease prevention. Ed. V.R. Preedy, Elsevier, pp. 483-490.

27. John, S.M., Deeseenthum, S. (2015). Properties and benefits of kefir-A review. Songklanakarin Journal of Science and Technology, 37 (3), 275-282.

28. Karabin, M., Jelinek, L., Kincl, T., Hudcova, T., Kotlikova, B., Dostalek, P. (2013). New approach to the production of xanthohumol-enriched beers. Journal of the Institute of Brewing, 119, 98-102.

29. Kerpes, R., Fischer, S., Becker, T. (2017). The production of gluten-free beer: Degradation of hordeins during malting and brewing and the application of modern process technology focusing on endogenous malt peptidases. Trends in Food Science and Technology, 67, 129-138.

30. Knorr, V., Wieser, H., Koehler, P. (2016). Production of gluten-free beer by peptidase treatment. European Food Research and Technology, 242 (7), 1129-1140.

31. Kondo, K. (2003). Preventive effects of dietary beer on lifestyle. The $29^{\text {th }}$ EBC Congress, Dublin, Proceedings, p.133.

32. Krottenthaler, M. (2009). Hops. In Handbook of brewing. Ed. H.M. Eßlinger, Wiley-VCH Verlag $\mathrm{GmbH}$ and Co, Weinheim, pp. 85-104.

33. Kusowski, J., Durham R, Pinto R. (2018). Fermented tea beer. Columbus, OH (US). US2018057779.

34. Lau, T-C., Chan, M-W., Tan, H-P., Kwek, C-L. (2013). Functional food: A growing trend among the health conscious. Asian Social Science, 9, 198-208. 
35. Leskošek-Ćukalović, I., Despotović, S., Lakić, N., Nikšić, M., Nedović, V., Tešević, V. (2010a). Ganoderma lucidum - Medical mushroom as a raw material for beer with enhanced functional properties. Food Research International, 43, 2262-2269.

36. Leskošek-Ćukalović, I., Despotović, S., Nedović, V., Lakić, N., Nikšić, M. (2010b). New type of beer - beer with improved functionality and defined pharmacodynamic properties. Food Technology and Biotechnology, 48, 384391.

37. Liangyun, S. (2017a). Beer containing L-carnitine. CN106916676.

38. Liangyun, S. (2017b). Bitter gourd and celery healthcare beer. CN106916673.

39. Liangyun, S. (2017c). Fresh ginger beer capable of warming uterus. CN106916663.

40. Lunder, T. (1989). Tannings of green and black tea: nutritional value, physiological properties and determination. Pharmaceutisch Tijdschrift voor Belgie, 66, 34-42.

41. Magalhães, P.J., Dostalek, P., Cruz J.M., Guido, L.F., Barros, A.A. (2008). The impact of a xanthohumol-enriched hop product on the behavior of xanthohumol and isoxanthohumol in pale and dark beers: A pilot scale approach. Journal of the Institute of Brewing, 114, 246256.

42. Mortazavian, A.M., Mohammadi, R., Sohrabvandi, S. (2012). Delivery of probiotic microorganisms into gastrointestinal tract by food products. In New advances in the basic and clinical gastroenterology. Ed. T. Brzozowski, InTech, Croatia, pp. 121-146.

43. Obisesan, T.O., Hirsch, R., Kosoko, O., Carlson, L. and Parrott, M. (1998). Moderate wine consumption is associated with decreased odds of developing age-related macular degeneration in NHANES-1. Journal of the American Geriatrics Society, 46 (1), 1-7.

44. Possemiers, S., Bolca, S., Grootaert, C., Heyerick, A., Decroos, K., Dhooge, W, De Keukeleire, D., Rabot S, Verstraete, W, Van de Wiele, T. (2006). The prenylflavonoid isoxanthohumol from hops (Humulus lupulus L.) is activated into the potent phytoestrogen 8prenylnaringenin in vitro and in the human intestine. The Journal of Nutrition, 136 (7), 1862-1867.

45. Possemiers, S., Verstraete, W., Wiele, T-V. (2009). Estrogenicity of beer: The role of intestinal bacteria in the activation of the beer flavonoid isoxanthohumol. In Beer in health and disease prevention. Ed. V.R. Preedy, Elsevier, pp. 523-539.

46. Rodrigues, K.L., Araújo, T.H., Schneedorf, J.M., Ferreira, C.S., Moraes, G.O.I., Coimbra, R.S., Rodrigues, M.R. (2016). A novel beer fermented by kefir enhances anti-inflammatory and anti-ulcerogenic activities found isolated in its constituents. Journal of Functional Foods, $21,58-69$.

47. Rodrigues, K.L., Carvalho, J.C.T., Schneedorf, J.M. (2005). Anti-inflammatory properties of kefir and its polysaccharide extract. Inflammopharmacology, 13 (5), 485-492.
48. Rosell C.M., Matos M.E. (2015). Market and nutrition issues of gluten-free foodstuff. In Advances in the understanding of gluten related pathology and the evolution of gluten-free foods. Eds. E. Arranz, F. Fernández-Bañares, C.M. Rosell, L. Rodrigo, A.S.Peña, OmniaScience, Barcelona, pp. 675-713.

49. Rozada-Sanchez, R., Sattur, A.P., Thomas, K., Pandiella, S.S. (2008). Evaluation of Bifidobacterium spp. for the production of a potentially probiotic malt-based beverage. Process Biochemistry, 43, 848-854.

50. Russel, I. (2006). Innovation and novel products. In Handbook of brewing (Second edition). Eds. F.G. Priest, G.G. Stewart, Taylor and Francis Group, London, UK, pp. 817-821.

51. Sobrahvandi, S., Razavi, S.H., Mousavi, S.M., Mortazavian, A.M. (2010). Viability of probiotic bacteria in low alcohol- and non-alcoholic beer during refrigerated storage. Philippine Agricultural Scientist, 93, 24-28.

52. Sohrabvandi, S., Mortazavian, A.M., Rezaei, K. (2012). Health-related aspects of beer: A review. International Journal of Food Properties, 15, 350-373.

53. Stevens, J.F., Page, J.E. (2004). Xanthohumol and related prenylflavonoids from hops and beer: to your good health! Phytochemistry, 65, 1317-1330.

54. Stevens, J.F., Taylor, A.W., Clawson, J.E., Deinzer, M.L. (1999). Fate of xanthohumol and related prenylflavonoids from hops to beer. Journal of Agricultural and Food Chemistry, 47, 2421-2428.

55. Stewart, G.G. (2013). Biochemistry of brewing. In Biochemistry of Foods. Ed. G.G. Stewart, Academic Press, San Diego, California, pp. 291-318.

56. Tamime, A.Y., Saarela, M., Sondergaard, A. K., Mistry, V.V., Shah, N.P. (2005). Production and maintenance of viability of probiotic microorganisms in dairy products. In Probiotic dairy products. Ed. T. Adnan, John Wiley \& Sons, Inc., New Jersey, USA, pp. 39-72.

57. Taylor, J.R.N., Dlamini, B.C., Kruger, J. (2013). $125^{\text {th }}$ anniversary review: the science of the tropical cereals sorghum, maize and rice in relation to lager beer brewing. Journal of the Institute of Brewing, 119, 1-14.

58. The Brewers of Europe (2017). Beer Statistics, Brussels, Belgium (Retrieved December, 2018 from

https://brewersofeurope.org/uploads/mycmsfiles/documents/publications/2017/Statistics201712-001.pdf).

59. Vadimovich, B.A., Arnoldovich, V.V. (2017). Mushroom beer and preparation method thereof. Obshchestvo s ogranichennoj otvetstvennostyu "Nauchno-Issledovatelskij Institut Mikotekhnologii" (OOO NII). RU2608497.

60. Veljović, M. (2016). Chemical, functional and sensory properties of beer enriched with biologically active compounds of grape, $P h D$ Thesis, Faculty of Agriculture, University of Belgrade, Serbia.

61. Veljović, M., Đorđević, R., Leskošek-Čukalović, I., Lakić, N., Despotović, S., Pecić, S., Nedović, 
V. (2010). The possibility of producing a special type of beer made from wort with the addition of grape must. Journal of the Institute of Brewing, 116 (4), 440-444.

62. Wunderlich, S., Zürcher, A., Back, W. (2005). Enrichment of xanthohumol in the brewing process. Molecular Nutrition and Food Research, 49, 874-881.

63. Yeo, H.Q., Liu, S.Q. (2014). An overview of selected specialty beers: developments, chal- lenges and prospects. International Journal of Food Science and Technology, 49, 1607-1618.

64. Yuen, J., Gohel, M. (2005). Anticancer effects of Ganoderma lucidum: A review of scientific evidence. Nutrition and Cancer, 5, 11-17.

65. Zhou, X., Lin, J., Yin, Y., Zhao, J., Sun, X., Tang, K. (2007). Ganodermataceae: Natural products and their related pharmacological functions. The American Journal of Chinese Medicine, 35, 559-574.

\title{
ПРЕГЛЕД ТРЕНДОВА У ФОРМУЛАЦИЈИ ФУНКЦИОНАЛНОГ ПИВА
}

\author{
Милана Ђ. Рошул ${ }^{* 1}$, Анамарија И. Мандић ${ }^{1}$, Александра Ч. Мишан ${ }^{1}$, Наташа Р. Ђерић ${ }^{1}$, \\ Јелена Д. Пејин ${ }^{2}$ \\ ${ }^{1}$ Универзитет у Новом Саду, Научни институт за прехрамбене технологије у Новом Саду, \\ 21000 Нови Сад, Булевар цара Лазара бр. 1, Србија \\ ${ }^{2}$ Универзитет у Новом Саду, Технолошки фракултет, 21000 Нови Сад, \\ Булевар цара Лазара бр. 1, Србија
}

Сажетак: У последње време, свест потрошача о утицају исхране на здравље стално расте. Као одговор на то, данас је широм света повећана потражња потрошача за иновативним производима. У том контексту, тржиште специјалних пива је од скоро у центру пажње. Пиво је једно од најтраженијих нискоалкохолних пића на свету. Садржи нека ретка и важна биоактивна, функционална једињења. Користећи различиту опрему, технике и састојке који садрже биоактивна једињења, постоји могућност формулисања и производње различитих пива са потенцијалним здравственим предностима. Пиваре су препознале потенцијал за потпуно ново тржиште и почеле да производе функционална пива. Овај прегледни рад представља детаљан преглед доступних података у овој области. Нека од формулисаних пива су присутна на тржишту, док остало чине развијене формулације фрункционалних пива које су објављене у научним часописима или су у виду одобрених патената. Већина формулација односи се на пива са лековитим биљкама које се већ користе као медицинско биље. У овом раду су описана и пива са додатком гљиве Ganoderma lucidum, грожђа, ксантохумола, кефира и пробиотика.

Кључне речи: фрерментисано пиће, специјално пиво, биљке, Ganoderma, ксантохумол, пробиотици

Received: 5 November 2018

Received in revised form: 4 March 2019/15 April 2019

Accepted: 17 April 2019 